\title{
Salinity Stress: Toward Sustainable Plant Strategies and Using Plant Growth-Promoting Rhizobacteria Encapsulation for Reducing It
}

\author{
Roohallah Saberi Riseh ${ }^{1, *}$, Marzieh Ebrahimi-Zarandi ${ }^{2} \mathbb{D}$, Elahe Tamanadar ${ }^{1}$, Mojde Moradi Pour ${ }^{1}$ \\ and Vijay Kumar Thakur $3,4, *$ D \\ 1 Department of Plant Protection, Faculty of Agriculture, Vali-e-Asr University of Rafsanjan, \\ Rafsanjan 7718897111, Iran; E.Tamanadar72@gmail.com (E.T.); Moradi.mojde21@gmail.com (M.M.P.) \\ 2 Department of Plant Protection, Faculty of Agriculture, Shahid Bahonar University of Kerman, \\ Kerman 7618411764, Iran; ebrahimimarzieh@gmail.com \\ 3 Biorefining and Advanced Materials Research Center SRUC, Edinburgh EH9 3JG, UK \\ 4 School of Engineering, University of Petroleum \& Energy Studies (UPES), Dehradun 248007, India \\ * Correspondence: r.saberi@vru.ac.ir (R.S.R.); vijay.thakur@sruc.ac.uk (V.K.T.)
}

Citation: Saberi Riseh, R.; Ebrahimi-Zarandi, M.; Tamanadar, E.; Moradi Pour, M.; Thakur, V.K. Salinity Stress: Toward Sustainable Plant Strategies and Using Plant Growth-Promoting Rhizobacteria Encapsulation for Reducing It. Sustainability 2021, 13, 12758. https://doi.org/10.3390/su132212758

Academic Editors: Prateek Saxena,

Giuliano Bissacco and

Konstantinos Salonitis

Received: 5 October 2021

Accepted: 16 November 2021

Published: 18 November 2021

Publisher's Note: MDPI stays neutral with regard to jurisdictional claims in published maps and institutional affiliations.

Copyright: (c) 2021 by the authors. Licensee MDPI, Basel, Switzerland. This article is an open access article distributed under the terms and conditions of the Creative Commons Attribution (CC BY) license (https:// creativecommons.org/licenses/by/ $4.0 /)$.

\begin{abstract}
Salinity is one of the most important abiotic stresses that influences plant growth and productivity worldwide. Salinity affects plant growth by ionic toxicity, osmotic stress, hormonal imbalance, nutrient mobilization reduction, and reactive oxygen species (ROS). To survive in saline soils, plants have developed various physiological and biochemical strategies such as ion exchange, activation of antioxidant enzymes, and hormonal stimulation. In addition to plant adaption mechanisms, plant growth-promoting rhizobacteria (PGPR) can enhance salt tolerance in plants via ion homeostasis, production of antioxidants, ACC deaminase, phytohormones, extracellular polymeric substance (EPS), volatile organic compounds, accumulation of osmolytes, activation of plant antioxidative enzymes, and improvement of nutrients uptake. One of the important issues in microbial biotechnology is establishing a link between the beneficial strains screened in the laboratory with industry and the consumer. Therefore, in the development of biocontrol agents, it is necessary to study the optimization of conditions for mass reproduction and the selection of a suitable carrier for their final formulation. Toward sustainable agriculture, the use of appropriate formulations of bacterial agents as high-performance biofertilizers, including microbial biocapsules, is necessary to improve salt tolerance and crop productivity.
\end{abstract}

Keywords: salinity stress; PGPR; encapsulation; formulation; polymer

\section{Introduction}

Plants are exposed to a variety of biotic and abiotic stresses throughout their life. Salinity is one of the most important abiotic stresses that influences plant growth and productivity. About $20 \%$ of agricultural lands are affected by salinity, and this amount continuously increases [1]. Salinity is defined as the total concentration of dissolved salts in water. The accumulation of salts in the soil, particularly sodium and chloride ions, causes the salinization of agricultural lands. Salinity affects plant growth by ionic toxicity, osmotic stress, hormonal imbalance, the reduction in nutrient mobilization, and the production of reactive oxygen species (ROS) [2]. Therefore, salinity causes wilting, drying, and death of plants.

Plants respond to salinity stress at different levels, including physiological, biochemical, and molecular pathways. The main strategies of plants to survive under salt stress include the biosynthesis of osmoprotectants, activation of antioxidant enzymes, and synthesis of antioxidant compounds, ion homeostasis, ion transport and uptake, synthesis of polyamines and nitric oxide, and hormone modulation [1]. 
Plant growth-promoting rhizobacteria (PGPR) facilitate plant growth directly and indirectly. While PGPR stimulates plant growth by mobilizing nutrients in soils or producing growth regulators, they protect plants from pathogens with various mechanisms [3]. Salinity also reduces the microbial diversity of soils. In addition, salinity affects microbial activities such as soil respiration and soil enzyme activity [4]. However, extremophilic microorganisms have specific adaption strategies to live in saline soils [5]. Several studies revealed that PGPRs could enhance salt tolerance in plants via the production of antioxidants, ACC deaminase, indole-3-acetic acid (IAA), extracellular polymeric substance (EPS), and volatile organic compounds, improving nutrients uptake. The effects of salinity stress on plants, adaption, and the role of PGPRs in plant salt tolerance are shown in Figure 1 briefly.
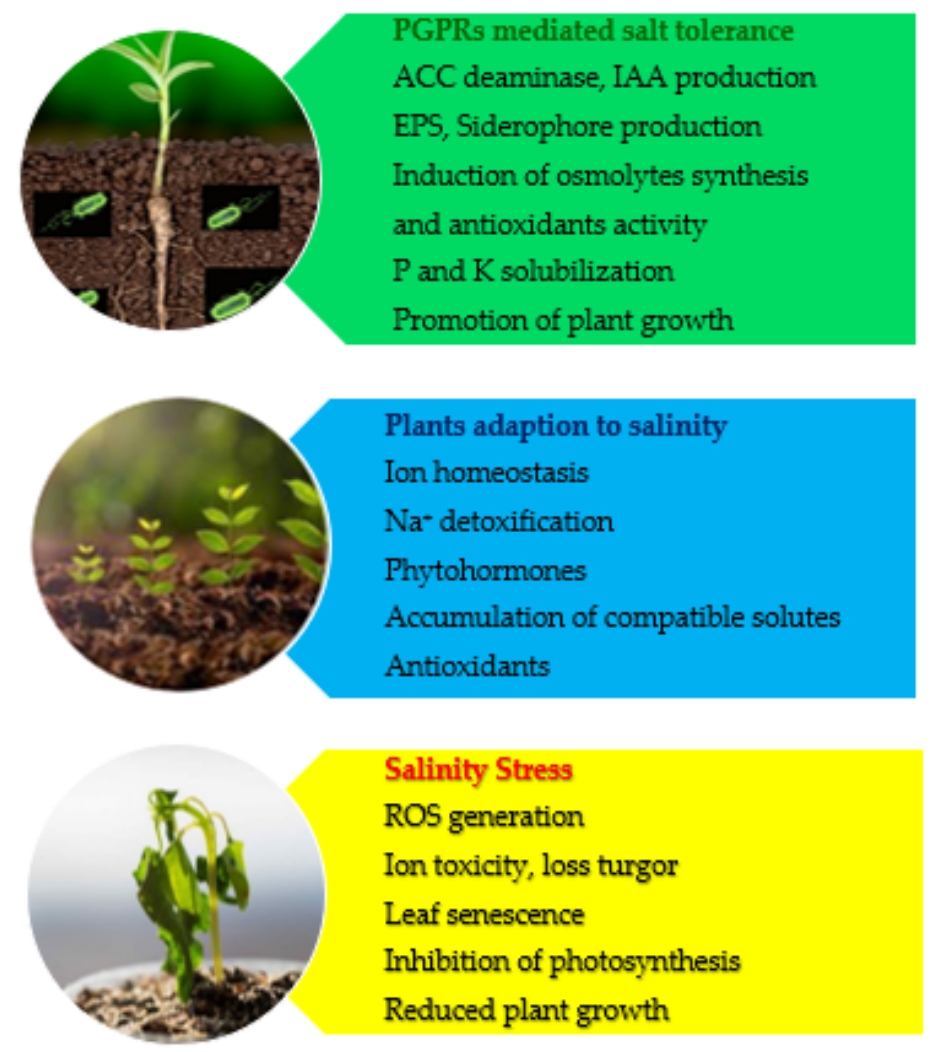

Figure 1. Impacts of salinity stress on plant, adaption, and PGPR-mediated salt tolerance.

The sustainability of plant yield under abiotic stress conditions requires integrating different strategies to alleviate stress impacts in plants. These strategies include the integrative application of beneficial microbes, osmoprotectants, nutrients, and chemical stimulants [6]. Although ideal bacterial agents have been reported during laboratory screenings, their application in the field has not been very successful. One of the reasons for this lack of success can be considered the adverse effect of environmental factors (including salinity stress) on the bacteria used, which reduces their efficiency and may kill them [7,8]. To increase their viability and improve their performance, it is necessary to add a suitable formulation of these factors in the soil. Encapsulation is a new formulation of bacterial agents that, during the gradual release in the soil, increase the survival of bacterial agents and thus improve their activity [9]. In addition to beneficial bacterial agents, the polymers used in this type of formulation can improve soil and plant conditions [10].

\section{Salinity and Its Effects on Plants}

Salinity is defined as the total concentration of dissolved salts in water. The accumulation of salts in soil, particularly sodium and chloride ions, causes the salinization of 
lands [2]. Soil salinization can be caused by agricultural practices including the overuse of fertilizers, insecticides, and fungicides, unsustainable use of the land, incorrect irrigation practices, wastewaters, and excessive drainage of the water tables [11]. The extreme of chemical or organic nitrogen fertilizers causes a rise in nitrate content in the soil that can be detected as a rise in the soil's electrical conductivity (EC). In addition, the application of fertilizers with a high potassium and sodium content can cause the accumulation of these salts under particular conditions and lead to soil degradation. In silty-clay soils under climate conditions, limited rainfall and high temperatures favor high evapotranspiration and the quick accumulation of salts in the first layers of the soil [12,13]. Measuring the electrical conductivity (EC) of the soil defines the salinity of that particular soil. In saline soil, the extract solution of the soil has an electrical conductivity of $20 \mathrm{mM}$ or more [14]. The acceptable limit of EC causing no damage to the crop is $<0.7 \mathrm{dS} / \mathrm{m}$, while an EC over $3.0 \mathrm{dS} / \mathrm{m}$ severely affects the crop yield [15]. Physiochemical characteristics of saline soils such as salt content, poor aeration, enhancement of crusting, reduced infiltration, and difficult root penetration affect plant growth and development [16].

Salinity stress is considered hyperionic or hyperosmotic stress. High salt accumulation in soil and plants cause osmotic stress. Therefore, water loss from leaves is accelerated. During the initial salinity stress, water absorption of the root system decreases $[17,18]$. Plants are more sensitive to salinity stress in their early growth stages compared to later development stages. The most sensitive stages of a plant's growth to salinity are germination and seedling [19]. Salinity affects the morphology, physiology, and biochemistry of plants and thus causes the significant reduction in crop yield. Ionic imbalance occurs due to the entrance of $\mathrm{Na}^{+}$and $\mathrm{Cl}^{-}$into the plant cells. Excessive uptake of these ions causes physiological disorders such as the reduction in seed germination, seedling growth, flowering, and fruiting. High $\mathrm{Na}^{+}$concentration inhibits the uptake of $\mathrm{K}^{+}$, which is an essential element for plant growth and development [20]. Salinity also leads to ROS formation and oxidative damage in cellular components such as proteins, lipids, and DNA [1]. Under saline stress, the leaf area and chlorophyll content of leaves decrease. In addition, the activity of photosystem II is inhibited during salinity stress, which leads to a reduction in photosynthetic efficiency [21]. Plants under salt stress show some morphological changes, including leaf thickening and succulence, decreased internode lengths, necrosis of organs or entire plants, wilting, and drying [22].

\section{Plant Strategies in Response to Salinity}

Plant species vary in salt tolerance depending on species, climate, soil type, its features, and agricultural practices. Plants based on adaptive evolution against salinity are classified into two types: halophytes and glycophytes. Most plant species are glycophytes that cannot withstand salinity $[4,23]$. To survive in saline soils, plants have developed various physiological and biochemical strategies, including the biosynthesis of osmoprotectants, activation of antioxidant enzymes and synthesis of antioxidant compounds, ion homeostasis, ion transport and uptake, synthesis of polyamines and nitric oxide, and hormone modulation [1]. Some of these strategies are discussed below.

\subsection{Osmoprotectants}

Compatible osmolytes protect the structure and maintain osmotic balance within the cell by continuous water influx. These compatible solutes or osmolytes consist of sugars, sugar alcohols, amino acid derivatives, and sulfonium compounds. Glycine betaine, sugars, proline, and polyols are the most important osmoprotectants [24]. As a response to salinity and drought stresses, soluble carbohydrates accumulate in plant tissues and lead to osmoprotection, osmotic adjustment, carbon storage, and radical scavenging. For example, trehalose is a disaccharide that accumulates in plants under various abiotic stresses and suppresses apoptotic cell death $[25,26]$.

In response to salt stress, the concentration of proline increases in plant cells while other amino acids such as cysteine, arginine, and methionine decrease [27]. In addition, 
the osmoprotectant, intracellular proline, also functions as an organic nitrogen reserve during stress recovery. Some reports have shown that proline improved salt tolerance by increasing the antioxidant enzyme activities, photosynthetic activity, plant growth, and preservation of plant water status under salt stress [28,29]. Glycine betaine is a quaternary ammonium compound mainly localized in chloroplasts and plays an essential function in photosynthetic efficiency and plasma membrane integrity [24]. This organic compound is also found in animals and microorganisms. Glycine betaine also protects the plant cell by osmotic adjustment, stabilizes proteins, and reduces ROS [30,31]. The accumulation of glycine betaine under salinity stress was reported to be high in some salt-tolerant plants. Its concentrations vary depending on species; for example, in sorghum, they are as much as tenfold higher than those in maize [32]. Under salt stress, the ultrastructure of rice seedlings showed several damages such as the swelling of thylakoids, the disintegration of grana and intergranal lamellae, and the disruption of mitochondria. However, the pretreatment of rice seedlings with glycine betaine prevented these damages [33,34].

Polyols or polyhydric alcohols are correlated with the tolerance to salinity and drought in plants, microbes, and animals [35]. Sugar alcohols are a class of polyols that play a role as compatible osmolytes and ROS scavenging compounds [31]. They exist in both acyclic and cyclic forms in plants. Acyclic forms of sugar alcohols are the most common in plants such as mannitol, glycerol, and sorbitol. These compatible solutes protect the cell and cause the stabilization of enzymes or membrane structures in stress periods. Mannitol synthesis is induced in plants under stress conditions. In addition, the accumulation of pinitol, a cyclic polyol, within the plant cell was reported during salinity stress [1].

\subsection{Antioxidants}

During biotic and abiotic stresses, the generation and accumulation of reactive oxygen species (ROS) occur in plants. ROS strongly oxidize compounds and are potentially harmful for cell integrity [36]. Antioxidant enzymes and nonenzymatic compounds play an essential role in detoxifying ROS induced by salinity and other stresses. Salt tolerance is positively correlated with the activity of antioxidant enzymes, including superoxide dismutase (SOD), catalase (CA), ascorbate peroxidase (APX), glutathione peroxidase (GPX), glutathione reductase (GR), and polyphenol oxidase (PPO). The activities of APX, monodehydroascorbate reductase (MDHAR), dehydroascorbate reductase (DHAR), and GR increased in shoots and decreased in the roots of wheat [37]. Under high salt concentration, higher activities of SOD, CA, APX, GR, and GST were detected in tomato plants [38]. Nonenzymatic compounds can enhance salt tolerance in plants. For example, silicon (Si) increased rice plant growth under salinity stress. The hormonal and antioxidant responses are affected by Si application to the rice root zone. Catalase, peroxidase, and polyphenol oxidase were more pronounced in control plants than in Si-treated plants under salinity stress [39]. There is strong evidence that anthocyanin accumulation occurs in plants under salt stress [40]. While ascorbate is one of the significant antioxidants in the plant cell, the exogenous application of this compound alleviates the adverse salinity impacts in plants and promotes plant recovery from stress [41,42]. In addition, the exogenous application of glutathione as a free radical scavenger mitigates the effects of salt stress in plants [43]. Other nonenzymatic antioxidants such as vitamins $C$ and $E$, carotenoids, and lipoic acid have been reported that can protect the plants against oxidative stress [44].

\subsection{Polyamines}

Polyamines are small, polycationic aliphatic molecules with low molecular weight in the plant kingdom. Putrescine, spermidine, and spermine are the most common polyamines found in plants. Putriscine as a diamine forms a primary substrate for higher polyamines such as spermidine and spermine $[45,46]$. When the plants are exposed to salinity stress, the endogenous polyamine level increases [47]. The application of exogenous polyamine increases the level of endogenous polyamine during stress. The positive effects of polyamine include maintaining membrane integrity, the reduction in ROS production, 
controlling the accumulation of $\mathrm{Na}^{+}$and $\mathrm{Cl}^{-}$ions in different organs, and the regulation of gene expression for the synthesis of osmolytes [48-50]. In arabidopsis, mutants of polyamine biosynthesis genes showed sensitivity to salinity [51]. The overexpression of putrescine, spermidine, and spermine enhanced salt tolerance in rice, tobacco, and Arabidopsis [52]. Spermidine and spermine are inducers of $\mathrm{NO}$, another critical signaling molecule involved in salt tolerance [53].

\subsection{Hormone Regulation}

Abscisic acid (ABA) is considered a stress phytohormone that mitigates the adverse effects of stresses in plants. The expression of ABA is upregulated under osmotic stress in plants. Salinity causes water deficit and osmotic stress; therefore, the production of ABA increases in shoots and roots [54]. ABA is an important cellular signal that modulates the expression of several salt and osmotic stress-responsive genes [55]. Salicylic acid (SA) and brassinosteroids (BR) also respond to abiotic stresses in plants. The endogenous level of SA and the activity of SA biosynthetic enzymes increased in rice seedlings under salt stress [56]. The exogenous application of SA and BR leads to improved salt tolerance in plants [57]. In barley, the SA led to the enhancement of chlorophyll content and carotenoids and maintained membrane integrity under saline conditions [58]. The application of BR enhanced the SOD, POX, APX, and GPX activity and the accumulation of tocopherol, ascorbate, and reduced glutathione [59].

\section{PGPR Enhance Salt Tolerance in Plants}

Plant growth-promoting rhizobacteria (PGPR) are well known to improve plant growth and disease reduction by several mechanisms such as the production of plant growth regulators, secondary metabolites, and nitrogen fixation, enhancement of the availability of different mineral nutrients, decomposition of organic matter, and induction of resistance in plants against various pathogens [60].

Salinity reduces the microbial diversity of soils and affects microbial activities such as soil respiration and soil enzyme activity [4]. However, extremophilic microorganisms have specific adaption strategies to live in saline soils [5]. Several studies revealed that PGPR could enhance salt tolerance in plants via ion homeostasis, the production of antioxidants, ACC deaminase, phytohormones, extracellular polymeric substance (EPS), volatile organic compounds, the accumulation of osmolytes, the activation of plant antioxidative enzymes, and the improvement of nutrient uptake [61].

\subsection{Improvement of Nutrient Uptake and Solubilisation}

The uptake of essential plant nutrient elements such as nitrogen, phosphorous, and potassium reduces under salinity stress. PGPRs are well known to improve nutrient uptake and solubilization [62,63]. Studies have confirmed that PGPR increases plants' nitrogen uptake by symbiotic and nonsymbiotic mechanisms [64]. Rhizobium sp. Is the prominent example of the symbiotic association for the biological fixation of N2 in plants. Rhizobium performs well in establishing nodules on the root of legumes at saline soils and improves legumes' growth under stress conditions [65]. Other nitrogen-fixing bacteria such as Azospirillum, Azotobacter, Burkholderia, Bacillus, and Paenibacillus are not plant-specific [66].

Phosphorous $(\mathrm{P})$ is another essential macronutrient and is taken up by plant roots in $\mathrm{H}_{2} \mathrm{PO}_{4}{ }^{-}$or $\mathrm{HPO}_{4}{ }^{2-}$-soluble forms. Under natural conditions, $\mathrm{P}$ is primarily unavailable to plants because of its precipitation in soil. Halotolerant PGPR can convert unavailable phosphorous into available phosphorus by the acidification, ion exchange, and chelation mechanisms under salt conditions $[67,68]$. Potassium $(\mathrm{K})$ plays an essential role in plant metabolisms, grain filling, and promoting plant resistance against biotic and abiotic stresses [69]. Naturally, most of the potassium of soil is not directly available for plants. Moreover, salinity stress decreases the availability of this element. K-solubilizing bacteria can improve the solubilization of potassium in soils even under salt stress [70]. PGPR can increase the availability of other nutrient elements such as $\mathrm{Fe}, \mathrm{Cu}, \mathrm{Zn}$, and $\mathrm{Mn}$ to plants [71]. 
Siderophore production is a mechanism that PGPR applies to iron acquisition from the environment in competition with pathogens. Siderophores are small molecules with a high affinity to $\mathrm{Fe}^{3+}$. Siderophores function as plant growth promotors and inducers of resistance in plants against pathogens. Many PGPRs such as actinobacteria, Pseudomonas spp., and Bacillus spp. produce siderophores [72]. Salinity reduces Fe availability due to the inhibition of proton pumps. Siderophore-producing bacteria have been shown to enhance salt tolerance in several plant models $[73,74]$.

\subsection{Production of ACC Deaminase}

Ethylene as a growth hormone produces endogenously in plants. The ethylene production is accelerated in plants under various stresses, including salinity, which adversely affects plant growth. Some of the PGPR can produce 1-amminocyclopropane-1-carboxylate (ACC) deaminase, which regulates ethylene production. Therefore, the adverse effects of elevated ethylene levels can be mitigated by PGPR under salinity conditions. In several studies, the production of ACC deaminase is one of the main reasons bacteria mediated plant growth promotions under salt stress (Table 1), for example, Pseudomonas fluorescens in groundnut [75], Streptomyces sp. in tomato [76], and Serratia sp. SL-12 in wheat [77]. Barnawal et al. [78] reported that Arthrobacter protophormiae with ACC deaminase activity protected pea plants against salinity stress. In another study, PGPR with ACC deaminase activity induced salt tolerance in sunflower [79]. Halotolerant Bacillus spp. strains showed that induced salinity stress can help wheat seed germination and seedling growth by producing ACC deaminase [80].

Table 1. Alleviation of impacts of salinity stress on plants by PGPR-containing ACC deaminase.

\begin{tabular}{ccc}
\hline Plant Species & Bacterial Strain & References \\
\hline & Burkholderia sp. MTCC 12259 & {$[81]$} \\
Wheat (Triticum aestivum L.) & Serratia sp. SL-12 & {$[77]$} \\
& Klebsiella sp. SBP-8 & {$[82]$} \\
& Bacillus pumilus FAB10 & {$[83]$} \\
Pea (Pisum sativum L.) & Chryseobacterium gleum sp. SUK & {$[84]$} \\
\hline Tomato (Solanum lycopersicum L.) & Arthrobacter protophormiae & {$[78]$} \\
\hline Peppers (Capsicum annuum L.) & Streptomyces sp. & {$[76]$} \\
\hline Arabidopsis thaliana & Bacillus sp. & {$[85]$} \\
Barley (Hordeum vulgare L.) & Hartmannibacter diazotrophicus E19 & {$[86]$} \\
\hline Mung bean (Vigna radiata L.) & Pseudomonas syringae Pseudomonas & {$[87]$} \\
& fluorescens Rhizobium phaseoli & {$[88]$} \\
\hline
\end{tabular}

\subsection{Production of IAA}

Indole-3-acetic acid (IAA) is the main auxin that promotes plant growth and is involved in many processes such as root development, seed germination, and plant tolerance against stresses [89]. Some PGPR produce this hormone, mainly actinobacteria species such as Streptomyces sp., Kitatospora sp., Nocardia sp., and Frankia sp. [90-92]. IAA functions as an effector molecule between bacteria and plants in bacteria and bacteria interactions [93]. The salt-tolerant actinomycetes strain increased tomato plant growth by several mechanisms, including IAA production [94]. Several studies have demonstrated that PGPR, with the ability to produce IAA, can improve plant growth under salinity stress. For example, IAAproducing Rhizobium bacteria improved rapeseed seedlings growth under salt stress [95]. Abeer et al. [96] revealed that $B$. subtilis promoted Indian bassia plants growth by producing IAA and reducing ethylene levels under salinity conditions. 
Other phytohormones such as cytokinins, gibberellins, and abscisic acid (ABA) are regulated by PGPR under salt stress. ABA mitigates the effects of high salinity by accumulating compatible solutes and cations, including $\mathrm{Ca}^{2+}$ and $\mathrm{K}^{+}$in root vacuoles [97].

\subsection{Production of EPS}

Bacteria produce extracellular Polymeric Substances (EPS) under natural conditions. It has been reported that EPS-producing PGPB can alleviate salinity stress [98,99]. Indeed, most of the bacteria can survive under stress conditions by the production of EPS. EPS includes biopolymers such as polysaccharides, polyamides, and polyesters. Under salinity stress, bacteria form biofilms as a common property. The structural stability of the biofilm is maintained by EPS [100]. EPS also plays a role in the establishment of plant-microbe interactions [98]. EPS alleviates the adverse effects of salinity stress by reducing the $\mathrm{Na}^{+}$ content available for plant uptake [99]. The formation of biofilm by salt-tolerant Halomonas variable and Planococcus rifietoensis caused an improvement of plant growth and aggregation of soil under salt stress [101].

\subsection{Other Mechanisms}

The production of volatile organic compounds (VOCs) by PGPR increases plant growth and modulates stress responses. VOCs are low-molecular-weight compounds, including ketones, aldehydes, alcohols, and hydrocarbons. VOCs emitted by PGPR can stimulate many chemical and physical changes, which improve plants tolerance against abiotic stresses [102]. B. subtilis GB03 produces VOCs, which stimulate many hormonal signals in Arabidopsis such as auxin, cytokinins, brassinosteroids, gibberellins, and salicylic acid [103,104]. The production of 2-undecanone, 7-hexanol, and 3-methylbutanol by Paraburkholderia phytofirmans led to salinity stress tolerance and enhancement of plant growth [105]. Other compounds produced by PGPR, such as enzymatic and nonenzymatic antioxidants, bacteriocins, osmolytes, including polyamines, sugars, sugar alcohols, betaines, and amino acids, can stimulate salt tolerance in plants [2].

\section{Formulation Technology}

One of the critical issues in microbial biotechnology is establishing a link between the beneficial strains screened in the laboratory and the consumer industry. Therefore, in developing beneficial factors such as microbial biocontrol agents, it is necessary to study the optimization of nutritional and physiological conditions for mass production and select a suitable carrier for the formulation. In addition to the efficiency of the biocontrol agent, it must become one of the standard formulations so that it can be mass-produced and widely used. Various carriers such as kaolin, talc, soil, and sand are used in microbial formulations. Today, polymeric materials (carbohydrates, proteins, and lipids) have a special place in the formulation due to their high ability to absorb and retain water and biological products [106]. The stability of fertilizers and biocontrol agents during storage and after use is one of the problems in production. As the production and storage conditions of the formulation are significant in preserving microbial populations and play a key role in its effectiveness and marketing, it can be said that the final product formulation is the culmination of knowledge in fertilizer production technology and biocontrol agents [107], and the acquisition of new practical formulations plays an essential role in agriculture.

\subsection{Encapsulation}

One of the effective formulations that has been considered by many sciences today, including agriculture, is the encapsulation of microbial agents. Microbial agents trapped in this formulation, while gradually releasing, increase their chances of survival under adverse environmental conditions and, as a result, increase their efficiency by increasing the percentage of colonization. Encapsulation is the continuous coating around an internal matrix that encloses the inside of the capsule wall as a core. In recent studies, it has been suggested to use various methods such as encapsulation of PGPR to increase their efficiency 
and survival for obtaining a good biofertilizer. Encapsulation is performed by multiple processes such as extrusion, emulsion, and spray drying (Figure 2). Different polymers are used for encapsulation and other multiple applications, which can be referred to as alginate, gelatin, gum arabic, xanthan, gellan gum, whey protein, chitosan, starch, etc. [108]. The most important of these is alginate [109]. With these various and available materials, it is possible to create capsules that are released under different conditions.

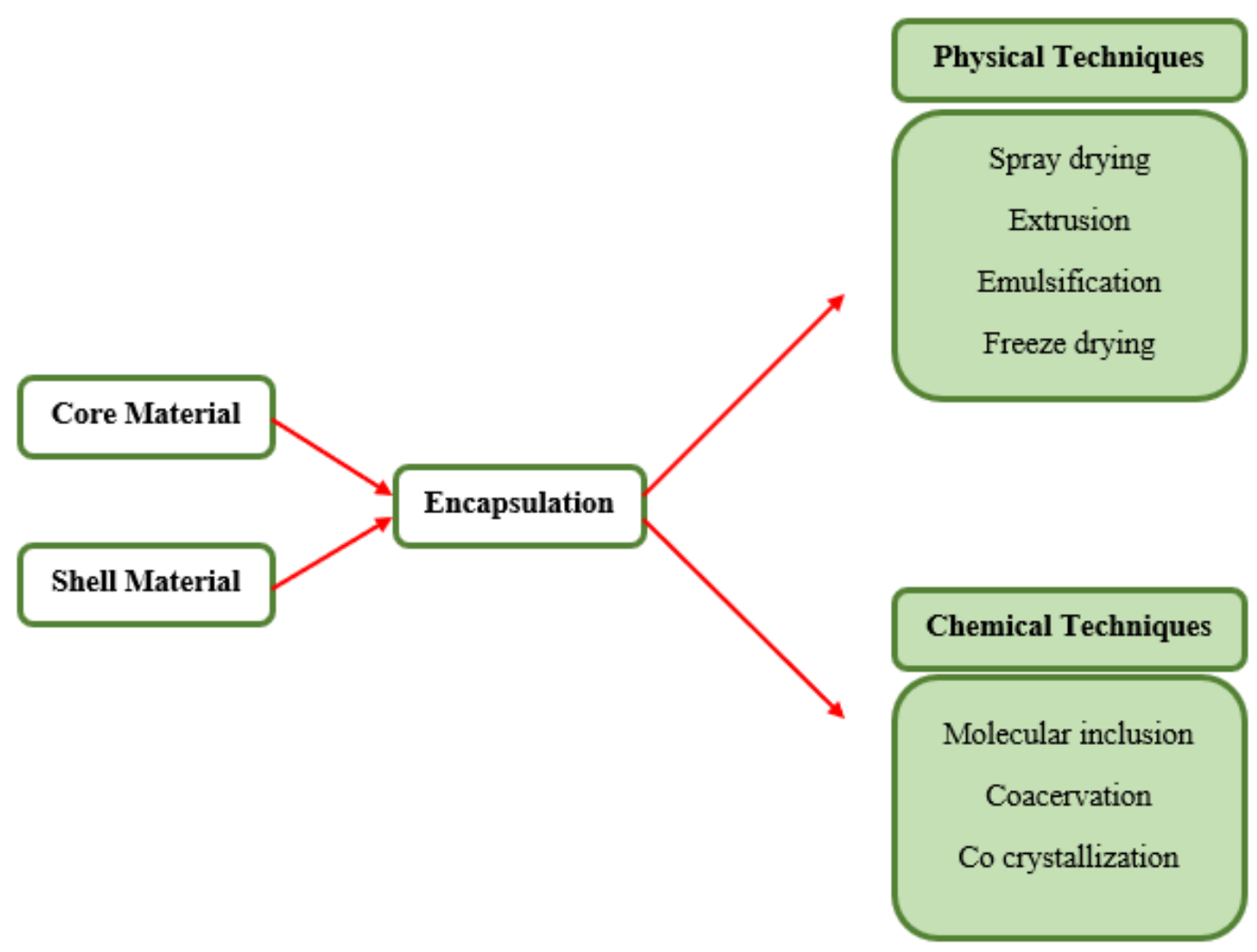

Figure 2. Various techniques for encapsulation of bacteria.

\subsection{Bacterial Encapsulation with Various Polymers against Salinity Stress}

Salinity stress increases ethylene production in the plant, which in most cases acts as a stress hormone [110]. Recent research has shown that plants inoculated with PGPR containing ACC deaminase can grow better under salinity conditions. Achromobacter piechaudii has ACC deaminase activity and was able to increase the growth of tomato plants in the presence of $\mathrm{NaCl}$ salt (up to $172 \mathrm{mM}$ ) [111]. However, microorganisms are quickly wasted in the environment and do not have long-term effectiveness. To accomplish this, the process of encapsulating bacteria is used to increase their efficiency.

The survival rate of Pseudomonas putida Rs 198 encapsulated with sodium alginate, bentonite, and starch on cotton roots under saline conditions has been investigated. The results indicated that the encapsulation of alginate, starch, and bentonite survival rate of P. putida Rs-198, in free and encapsulated bacteria, after 50 days of storage is $81.07 \%$ and $89.67 \%$, respectively [112]. P. putida Rs-198 in microcapsules has higher survival and colonization rates than free cells do on cotton roots, and encapsulated P. putida Rs-198 could produce as many gibberellins and auxin as free cells on cotton roots cells, with or without salt stress [113]. Therefore, it can be stated that a suitable formulation by encapsulating PGPR with alginate, starch, and bentonite to reduce salt stress in cotton plants will be beneficial in sustainable agriculture [114]. Encapsulation by alginate and granule formation is based on mineral carriers such as zeolite with the help of Parabukholderia phytofirmans PsJN, which is a Gram-negative bacterium that was formulated as formulation techniques to obtain stable inoculations. The survival of this bacterium was examined 
for seven months [115]. It was found that choosing the right formulation increases the survival of PsJN by up to 100,000 times. Alginate particles (less than 100 microns) are very efficient for coating formulations [116]. This study investigated two different approaches to formulating beneficial plant bacteria, including alginate encapsulation and immobilization in zeolite particles. Both methods yielded inoculants with morphological characteristics suitable for seed coating and in-furrow placement, respectively. A critical factor in encapsulating alginate is the balance between sizes. This can be carried out by optimizing the matrix composition and choosing a suitable method such as extrusion. Physical properties of zeolite-based inoculations, such as brittleness and extrudability, can be combined with the ratio of zeolite and additives. The results showed that the formulation of Paraburkholderia phytofirmans PsJN's viability is much higher than that of Bacillus subtilis during drying [117]. The formulations of Pseudomonas fluorescens and Burkholderia cepacia with phosphate alginate showed improved growth of wheat plants in semi-arid and saline stress areas [118]. Bacterial strains of Pseudomonas fluorescens BAM-4 and Burkholderia cepacia BAM-12 were immobilized using sodium alginate and alginate-skim milk as a carrier to check the phosphate solubilization in vitro and were found to have a significantly higher activity than the control. Their effectiveness was also tested in vivo on the growth of wheat plants in semi-arid potted conditions. Another study on soil salinity showed that cyanobacteria Cyanothece sp. and Rhizobacter enterobacter cloacae were encapsulated with methyl salicylate [119]. In addition, various nanomaterials such as graphene, graphene oxide, and carbon nanotubes were used in combination with biofertilizers against soil salinity in encapsulated form. Nanosized materials can act as desalination hives as soil salt ion removal agents during irrigation, reducing soil salinity [120]. Graphene oxide is the most plausible candidate because of its hydrophilicity and favorable spectral interaction with algae with no detectable inhibition of photosynthesis [121]. When released from a capsule, the rhizobacterium will colonize the root zone and allow for more efficient water and nutrient absorption as it produces a growth hormone that enhances root growth. The cyanobacterium, when released, would also allow for the bioavailability of nutrients and nitrogen fixation, as well as the production of an array of growth hormones and biostimulants. Graphene oxide and graphene represent promising candidates for inclusion with biofertilizers in the treatment of salinized soils, but again, the type of plant should be considered [122]. To increase survival and better performance of Azospirillum lipoferum, it was encapsulated with alginate, and one year after encapsulation, the bacterial population was $1010 \mathrm{CFU} \mathrm{g}^{-1}$, which was used to solve the salinity problem of the sorghum field [123].

\subsection{Examples of Using PGPR Encapsulation against Salinity Stress in Different Plants}

Microcapsules containing Klebsiella oxytoca Rs-5 were prepared for the growth of cotton plants under salinity stress [124]. The survival rate of encapsulated bacteria after 14, 21 , and 28 days in the soil was calculated as close to $90 \%$. In addition, the treatment of cotton with bacteria reduced salinity stress factors and increased cotton plant growth [124]. Physiological parameters in cotton containing a bacterial encapsulation such as chlorophyll a, soluble sugar, malondialdehyde, and proline were better than cotton without cotton encapsulation conditions. Microencapsulated bacteria also effectively increased superoxide dismutase, peroxidase, and catalase activity in cotton. The use of K. oxytoca Rs-5 capsules increased seed germination and plant growth under salinity stress and can also be valuable and effective as a biological fertilizer [124]. Another study on the confinement of Pantoea agglomerans KL with sodium alginate by Komal et al. [125] on rice under greenhouse conditions showed that the pressure used showed a decrease in salinity stress (100 $\mathrm{mM}$ of $\mathrm{NaCl}$ ) and has been effective in increasing the growth of rice plants. In addition, malondialdehyde had a significant effect on plant growth in elongation, biomass, and photosynthetic pigment, and decreased proline levels. In addition, an increase in calcium and potassium absorption and a decrease in sodium was observed in the plant-containing a bacterial encapsulation. In addition, electron microscopic analysis of the roots of plants with salinity stress showed significant colonization of the roots by encapsulation. It can be 
stated that the research showed the ability of P. aglomerans encapsulation of the KL strain to increase plant growth and improve salinity stress [125]. To reduce salinity and increase the yield of plants under salinity stress, another study on the bean plant by encapsulating bacteria Rhizobium tropici CIAT 899 was performed, and it was shown that rhizobacteria, after the dissolution of the coating contaminates the plant roots, formed nodules in the roots, increased plant yield and germination, and ultimately reduced soil salinity [126]. In this study, a biomaterial formulation was used to improve the coverage of seeds with biofertilizers and their release into the soil to increase seed germination and reduce soil salinity. Increased survival of encapsulated bacteria and its gradual release resulted in acceptable soil performance [126]. Another study was performed using calcium-alginate microcapsules with Klebsiella oxytoca strain Rs-5 for the survival of cotton plants under salinity stress [114]. In this study, sodium alginate and calcium chloride were used as capsule wall coatings, which showed that the activity of microcapsules was best when using the sodium alginate concentration, while the particle size of the microcapsules was 0.85-1.10 $\mathrm{mm}$ [114]. The bacterial population released from the capsule was $1010 \mathrm{cfu} / \mathrm{g}$, which was studied for three weeks. Encapsulation of the bacteria with alginate caused the better growth of cotton plants under salinity stress under greenhouse conditions [114]. This study showed the encapsulation of sodium alginate with Azosprillum lipoferum and Paenibacillus polymyxa bacteria in a basil field under salinity stress in two growing seasons [127]. The PGPR bacteria improved the absorption of minerals such as potassium and phosphorus in the roots. It also increased plant growth, which increased the absorption of nutrients from the soil [128]. The microcapsules prepared in this study were a good soil improver for plant growth [129]. In addition, it was observed to improve soil structure and permeability in saline soils due to increasing salt leaching, reducing surface evaporation, and preventing the accumulation of salt in surface soil. Encapsulated bacteria can also increase plant growth under salinity stress directly or indirectly and in plant defense against ROS (reactive oxygen species), and they are related to defense systems including antioxidants such as catalase, peroxidase, superoxide dismutase, glutathione reductase, ascorbate peroxidase, and nonenzymatic compounds including ascorbate, $\alpha$-tocopherol, carotenoids, and ascorbate [130]. Exopolysaccharides produced by pseudomonads can bind to cations such as $\mathrm{Na}+$ and thus make them suitable for plants under salinity stress [130]. This research was conducted to evaluate the effect of the microencapsulation of three species of growth-promoting rhizobacteria, including Paenibacillus polymyxa MSRH5, Bacillus nakamurai MSRH1, and Bacillus pacificus MSRH3, on the growth and yield of wheat plants under salinity stress using sodium alginate (Triticum aestiv) [131]. The three strains MSRH1, MSRH3, and MSRH5 were characterized as salt-tolerant bacteria. P. polymyxa MSRH5 had a nitrogen fixation ability, while B. nakamurai MSRH1 and B. pacificus MSRH3 were able to solubilize phosphate and $\mathrm{K}$, respectively. Bacteria encapsulated with alginate were examined in wheat plant roots using a transmission electron microscope [131]. Under soil salinity conditions in two consecutive field trials, the results cleared those strains in two forms to succeed in colonizing the plant root. The reduction in shoot proline was $35.8 \%$ with capsules inoculation, the relative water content (\%) was improved to $60.57 \%$, and the electrolyte leakage recorded improved to $18.1 \%$ compared to the control. This encapsulation of bacteria prevented the destruction of wheat rhizospheres against salinity stress and its destruction [131]. As a result, it can be used to preserve wheat plants in areas with saline soils to increase yields [131]. The harmful effect of salinity stress on crops must be reduced. For this reason, the use of bacterial microencapsulation with methyl salicylate was investigated. The bacteria tested included the cyanobacterial strain Cyanothece sp. and the rhizobacterium Enterobacter cloacae, which was applied to wheat in the field [119]. The results showed that this encapsulation reduced the destructive effect of salinity stress, especially when combined with methyl salicylate. When nanomaterials were added to biofertilizers at the highest salinity, the salinity inhibitory effect was further reduced. Cyanothece sp. is a nitrogen-fixing and photosynthetic cyanobacterium that combines with a heterotrophic bacterium that actively inhales and consumes oxygen, thereby stabilizing 
nitrogen and producing $\mathrm{CO}_{2}$ during respiration, thereby facilitating photosynthesis. These nanomaterials have a high level and can act as desalination agents and ion removers from soil salt solution when irrigated with saltwater, thus reducing the effects of salinity [119]. When released from the capsule or delivered in mulch, Rhizobacterium colonizes the root zone and makes it more efficient to absorb water and nutrients by absorbing growth hormone, which increases root growth [122]. Similarly, when released, cyanobacteria can produce nutrient bioavailability and nitrogen fixation and the production of a set of growth hormones and bio-stimulants [132]. The effect of selenium and carrageenan (NC Se/Car) encapsulation was studied using Clavibacter michiganensis ssp. for better potato growth in salinity stress areas [133]. Electron microscope data showed that NC Se/Car contain microencapsulated selenium nanoparticles. Experiments on potato plants have shown the NC Se/Car stimulant effect on plant biometric indices and the reduction in harmful effects of salinity. These results indicate that this formulation can be used as a stimulant of plant growth and its resistance to salinity factors [133]. Examples of bacterial encapsulation by the polymer coating against salinity stress are shown in Table 2.

Table 2. Bacterial encapsulation by polymer coating against salinity stress.

\begin{tabular}{ccc}
\hline Bacteria & Coating & References \\
\hline Parabukholderia phytofirmans & Alginate & {$[115]$} \\
Pseudomonas fluorescens & Alginate & {$[118]$} \\
Burkholderia cepacia & Alginate & {$[118]$} \\
Cyanobacteria cyanothece & Methyl salicylate & {$[119]$} \\
Rhizobacter enterobacter & Methyl salicylate & {$[119]$} \\
Azospirillum lipoferum & Alginate & {$[123]$} \\
Pantoea agglomerans & Alginate & {$[125]$} \\
Klebsiella oxytoca & Calcium-Alginate & {$[114]$} \\
Azosprillum lipoferum & Alginate & {$[127]$} \\
Paenibacillus polymyxa & Alginate & {$[127]$} \\
Paenibacillus polymyxa & Alginate & {$[131]$} \\
Bacillus nakamurai & Alginate & {$[131]$} \\
Bacillus pacificus & Alginate & {$[131]$} \\
Cyanothece sp. & Methyl salicylate & {$[119]$} \\
Enterobacter cloacae & Methyl salicylate & {$[119]$} \\
Clavibacter michiganensis & Selenium + Aggregates & {$[133]$} \\
\hline
\end{tabular}

\section{Conclusions}

Salinity stress causes severe losses of agricultural crop productivity worldwide. Although breeding techniques have been used to improve salt tolerance and productivity in plants, these techniques are not cost-effective and have been unsuccessful in transferring salt tolerance to the target species in some cases. Plants' adaption to salinity stress involves complex pathways including physiological and metabolic networks. PGPR can help to overcome the adverse effects of salt stress in plants with various mechanisms. Thus, using efficient formulations of microbial agents as biofertilizers to improve salt tolerance and crop productivity is an essential step toward sustainable agriculture. The commercialization of microcapsules of bacterial agents and their supply to farmers can improve the yield of agricultural products and increase the quantity and quality of organic agricultural products. It is necessary to further study the survival of salt tolerance of PGPR in soils and the interactions of these bacteria with soil microflora and complex environmental factors.

Author Contributions: Conceptualization, R.S.R., V.K.T. and M.M.P.; writing-original draft preparation, R.S.R., M.E.-Z., E.T. and M.M.P.; writing-review and editing, R.S.R., M.E.-Z., E.T. and V.K.T. All authors have read and agreed to the published version of the manuscript.

Funding: This research received no external funding.

Institutional Review Board Statement: Not applicable. 
Informed Consent Statement: Not applicable.

Data Availability Statement: Not applicable.

Acknowledgments: R.S.R., M.M.P. and E.T. acknowledge Vali-e-Asr University of Rafsanjan for providing the research materials and funds

Conflicts of Interest: The authors declare no conflict of interest.

\section{References}

1. Gupta, B.; Huang, B. Mechanism of salinity tolerance in plants: Physiological, biochemical, and molecular characterisation. Int. J. Genom. 2014, 2014, 701596. [CrossRef] [PubMed]

2. Kumar, A.; Singh, S.; Gaurav, A.K.; Srivastava, S.; Verma, J.P. Plant growth-promoting bacteria: Biological tools for the mitigation of salinity stress in plants. Front. Microbiol. 2020, 11, 1216. [CrossRef] [PubMed]

3. Vejan, P.; Abdullah, R.; Khadiran, T.; Ismail, S.; Nasrulhaq Boyce, A. Role of plant growth promoting rhizobacteria in agricultural sustainability-A review. Molecules 2016, 21, 573. [CrossRef]

4. Shrivastava, P.; Kumar, R. Soil salinity: A serious environmental issue and plant growth promoting bacteria as one of the tools for its alleviation. Saudi J. Biol. Sci. 2015, 22, 123-131. [CrossRef] [PubMed]

5. Otlewska, A.; Migliore, M.; Dybka-Stępień, K.; Manfredini, A.; Struszczyk-Świta, K.; Napoli, R.; Białkowska, A.; Canfora, L.; Pinzari, F. When salt meddles between plant, soil and microorganisms. Front. Plant Sci. 2020, 11, 1429. [CrossRef] [PubMed]

6. Enebe, M.C.; Babalola, O.O. The influence of plant growth-promoting rhizobacteria in plant tolerance to abiotic stress: A survival strategy. Appl. Microbiol. Biotechnol. 2018, 102, 7821-7835. [CrossRef]

7. Moradi-Pour, M.; Saberi Riseh, R.; Mohammadinejad, R.; Hosseini, A. Investigating the formulation of alginate-gelatin encapsulated Pseudomonas fluorescens (VUPF5 and T17-4 strains) for controlling Fusarium solani on potato. Int. J. Biol. Macromol. 2019, 133, 603-613. [CrossRef]

8. Saberi-Riseh, R.; Moradi-Pour, M. A novel encapsulation of Streptomyces fulvissimus Uts22 by spray drying and its biocontrol efficiency against Gaeumannomyces graminis, the causal agent of take-all disease in wheat. Pest Manag. Sci. 2021, 2021. 77, 4357-4364. [CrossRef]

9. Saberi-Riseh, R.; Moradi-Pour, M.; Mohammadinejad, R.; Thakur, V.K. Biopolymers for Biological Control of Plant Pathogens: Advances in Microencapsulation of Beneficial Microorganisms. Polymers 2021, 13, 1938. [CrossRef]

10. Saberi Riseh, R.; Moradi Pour, M. The effect of Bacillus subtilis Vru1 encapsulated in alginate-bentonite coating enriched with titanium nanoparticles against Rhizoctonia solani on bean. Int. J. Biol. Macromol. 2020, 152, 1089-1097. [CrossRef]

11. Datta, K.K.; Jong, C.D. Adverse effect of waterlogging and soil salinity on crop and land productivity in northwest region of Haryana, India. Agric. Water Manag. 2002, 57, 223-238. [CrossRef]

12. Gkiougkis, I.; Kallioras, A.; Pliakas, F.-K.; Pechtelidis, A.; Diamantis, V.; Diamantis, J.; Ziogas, A.; Dafnis, I. Assessment of soil salinization at the eastern Nestos River Delta, N.E. Greece. Catena 2014, 128, 238-251. [CrossRef]

13. Chang, T.T.; Zhang, Y.J.; Xu, H.L.; Shao, X.H.; Xu, Q.C.; Li, F.L. Osmotic adjustment and up-regulation expression of stressresponsive genes in tomato induced by soil salinity resulted from nitrate fertilisation. Int. J. Agric. Biol. Eng. 2018, 11, 126-136.

14. De Souza, S.M.; Fay, F.E. Effect of salinity on soil microorganisms. In Soil Health and Land Use Management; Hernandez-Soriano, M.C., Ed.; IntechOpen: Rijeka, Croatia, 2014; pp. 177-198. [CrossRef]

15. Ayers, R.S.; Westcot, D.W. Water Quality for Agriculture; Food and Agriculture Organization of the United Nations: Rome, Italy, 1985; Volume 29.

16. Rogers, M.; Craig, A.D.; Munns, R.; Colmer, T.; Nichols, P.; Malcolm, C.; Barrett-Lennard, E.; Brown, A.; Semple, W.; Evans, P.; et al. The potential for developing fodder plants for the salt-affected areas of southern and eastern Australia: An overview. Aust. J. Exp. Agric. 2005, 45, 300-329. [CrossRef]

17. Munns, R.; Tester, M. Mechanisms of salinity tolerance. Annu. Rev. Plant Biol. 2008, 59, 651-681. [CrossRef]

18. Rahnama, A.; James, R.; Poustini, K.; Munns, R. Stomatal conductance as a screen for osmotic stress tolerance in durum wheat growing in saline soil. Funct. Plant Biol. 2010, 37, 255-263. [CrossRef]

19. Machado, R.M.A.; Serralheiro, R.P. Soil Salinity: Effect on vegetable crop growth. management practices to prevent and mitigate soil salinisation. Horticulturae 2017, 3, 30. [CrossRef]

20. James, R.A.; Blake, C.; Byrt, C.S.; Munns, R. Major genes for $\mathrm{Na}^{+}$exclusion, Nax1 and Nax2 (wheat HKT1;4 and HKT1;5), decrease $\mathrm{Na}^{+}$accumulation in bread wheat leaves under saline and waterlogged conditions. J. Exp. Bot. 2011, 62, 2939-2947. [CrossRef] [PubMed]

21. Mehta, P.; Jajoo, A.; Mathur, S.; Bharti, S. Chlorophyll a fluorescence study revealing effects of high salt stress on Photosystem II in wheat leaves. Plant Physiol. Biochem. 2010, 48, 16-20. [CrossRef] [PubMed]

22. Saberi Riseh, R.; Skorik, Y.A.; Thakur, V.K.; Moradi Pour, M.; Tamanadar, E.; Noghabi, S.S. Encapsulation of Plant Biocontrol Bacteria with Alginate as a Main Polymer Material. Int. J. Mol. Sci. 2021, 22, 11165. [CrossRef]

23. Flowers, T.J. Improving crop salt tolerance. J. Exp. Bot. 2004, 55, 307-319. [CrossRef] [PubMed] 
24. Yokoi, S.; Quintero, F.; Cubero, B.; Ruiz, M.; Bressan, R.; Hasegawa, P.; Pardo, J. Differential expression and function of Arabidopsis thaliana $\mathrm{NHX} \mathrm{Na}{ }^{+} / \mathrm{H}^{+}$antiporters in the salt stress response. Plant J. 2002, 30, 529-539. [CrossRef]

25. Parvaiz, A.; Satyawati, S. Salt stress and phyto-biochemical responses of plants-A review. Plant Soil Environ. 2008, 54, 89. [CrossRef]

26. Yamada, T.; Takatsu, Y.; Manabe, T.; Kasumi, M.; Marubashi, W. Suppressive effect of trehalose on apoptotic cell death leading to petal senescence in ethylene-insensitive flowers of gladiolus. Plant Sci. 2003, 164, 213-221. [CrossRef]

27. El-Shintinawy, F.; El-Shourbagy, M.N. Alleviation of changes in protein metabolism in NaCl-stressed wheat seedlings by thiamine. Biol. Plant. 2001, 44, 541-545. [CrossRef]

28. Hoque, M.A.; Banu, M.N.; Nakamura, Y.; Shimoishi, Y.; Murata, Y. Proline and glycinebetaine enhance antioxidant defense and methylglyoxal detoxification systems and reduce NaCl-induced damage in cultured tobacco cells. J. Plant Physiol. 2008, 165, 813-824. [CrossRef] [PubMed]

29. Ben Ahmed, C.; Ben Rouina, B.; Sensoy, S.; Boukhriss, M.; Ben Abdullah, F. Exogenous proline effects on photosynthetic performance and antioxidant defense system of young olive tree. J. Agric. Food Chem. 2010, 58, 4216-4222. [CrossRef]

30. Gadallah, M.A.A. Effects of proline and glycinebetaine on Vicia faba responses to salt stress. Biol. Plant. 1999, 42, 249-257. [CrossRef]

31. Ates, B.; Koytepe, S.; Ulu, A.; Gurses, C.; Thakur, V.K. Chemistry, Structures, and Advanced Applications of Nanocomposites from Biorenewable Resources. Chem. Rev. 2020, 120, 9304-9362. [CrossRef] [PubMed]

32. Agastian, P.; Kingsley, S.J.; Vivekanandan, M. Effect of salinity on photosynthesis and biochemical characteristics in mulberry genotypes. Photosynthetica 2000, 38, 287-290. [CrossRef]

33. Cha-Um, S.; Kirdmanee, C. Effect of glycinebetaine on proline, water use, and photosynthetic efficiencies, and growth of rice seedlings under salt stress. Turk. J. Agric. For. 2010, 34, 517-527.

34. Rahman, S.; Miyake, H.; Takeoka, Y. Effects of exogenous glycinebetaine on growth and ultrastructure of salt-stressed rice seedlings (Oryza sativa L.). Plant Prod. Sci. 2002, 5, 33-44. [CrossRef]

35. Bohnert, H.J.; Nelson, D.E.; Jensen, R.G. Adaptations to environmental stresses. Plant Cell 1995, 7, 1099-1111. [CrossRef] [PubMed]

36. Groß, F.; Durner, J.; Gaupels, F. Nitric oxide, antioxidants and prooxidants in plant defence responses. Front. Plant Sci. 2013, 4, 419. [CrossRef]

37. Meneguzzo, S.; Navam-Izzo, F.; Izzo, R. Antioxidative responses of shoots and roots of wheat to increasing NaCI concentrations. J. Plant Physiol. 1999, 155, 274-280. [CrossRef]

38. Rodríguez-Rosales, M.P.; Kerkeb, L.; Bueno, P.; Donaire, J.P. Changes induced by $\mathrm{NaCl}$ in lipid content and composition, lipoxygenase, plasma membrane $\mathrm{H}^{+}$-ATPase and antioxidant enzyme activities of tomato (Lycopersicon esculentum. Mill) calli. Plant Sci. 1999, 143, 143-150. [CrossRef]

39. Kim, Y.H.; Khan, A.L.; Waqas, M.; Shim, J.K.; Kim, D.H.; Lee, K.Y.; Lee, I.J. Silicon application to rice root zone influenced the phytohormonal and antioxidant responses under salinity stress. J. Plant Growth Regul. 2014, 33, 137-149. [CrossRef]

40. Van Oosten, M.J.; Sharkhuu, A.; Batelli, G.; Bressan, R.A.; Maggio, A. The Arabidopsis thaliana mutant air1 implicates SOS3 in the regulation of anthocyanins under salt stress. Plant Mol. Biol. 2013, 83, 405-415. [CrossRef] [PubMed]

41. Agarwal, S.; Shaheen, R. Stimulation of antioxidant system and lipid peroxidation by abiotic stresses in leaves of Momordica charantia. Braz. J. Plant Physiol. 2007, 19, 149-161. [CrossRef]

42. Munir, N.; Aftab, F. Enhancement of salt tolerance in sugarcane by ascorbic acid pretreatment. Afr. J. Biotechnol. 2011, 10, 18362-18370.

43. Foyer, C.; López-Delgado, H.; Dat, J.; Scott, I. Hydrogen peroxide and glutathion-associated mechanisms of acclimatory stress tolerance and signaling. Physiol. Plant. 2006, 100, 241-254. [CrossRef]

44. Kojo, S. Vitamin C: Basic metabolism and its function as an index of oxidative stress. Curr. Med. Chem. 2004, 11, 1041-1064. [CrossRef] [PubMed]

45. Knott, J.M.; Römer, P.; Sumper, M. Putative spermine synthases from Thalassiosira pseudonana and Arabidopsis thaliana synthesise thermospermine rather than spermine. FEBS Lett. 2007, 581, 3081-3086. [CrossRef] [PubMed]

46. Gupta, K.; Dey, A.; Gupta, B. Plant polyamines in abiotic stress responses. Acta Physiol. Plant. 2013, 35, 2015-2036. [CrossRef]

47. Takahashi, T.; Kakehi, J.-I. Polyamines: Ubiquitous polycations with unique roles in growth and stress responses. Ann. Bot. 2009, 105, 1-6. [CrossRef]

48. Roy, P.; Gupta, K.; SenGupta, D.N.; Ghosh, B. Spermidine treatment to rice seedlings recovers salinity stress induced damage of Plasma membrane and PM-bound H+- ATPase in salt-tolerant and salt sensitive Rice cultivars. Plant Sci. 2005, 168, 583-591. [CrossRef]

49. Roychoudhury, A.; Basu, S.; Sengupta, D.N. Amelioration of salinity stress by exogenously applied spermidine or spermine in three varieties of indica rice differing in their level of salt tolerance. J. Plant Physiol. 2011, 168, 317-328. [CrossRef]

50. Afzal, I.; Munir, F.; Ayub, C.; Basra, S.; Hameed, A.; Nawaz, A. Changes in antioxidant enzymes, germination capacity and vigour of tomato seeds in response of priming with polyamines. Seed Sci. Technol. 2009, 37, 765-770. [CrossRef]

51. Yamaguchi, K.; Takahashi, Y.; Berberich, T.; Imai, A.; Miyazaki, A.; Takahashi, T.; Michael, A.; Kusano, T. The polyamine spermine protects against high salt stress in Arabidopsis thaliana. FEBS Lett. 2006, 580, 6783-6788. [CrossRef] 
52. Shevyakova, N.; Musatenko, L.; Stetsenko, L.; Vedenicheva, N.; Voitenko, L.; Sytnik, K.; Kuznetsov, V. Effects of abscisic acid on the contents of polyamines and proline in common bean plants under salt stress. Russ. J. Plant Physiol. 2013, 60, $200-211$. [CrossRef]

53. Moschou, P.N.; Paschalidis, K.A.; Roubelakis-Angelakis, K.A. Plant polyamine catabolism: The state of the art. Plant Signal. Behav. 2008, 3, 1061-1066. [CrossRef]

54. Cabot, C.; Sibole Iii, J.; Barceló, J.; Poschenrieder, C. Abscisic Acid Decreases Leaf Na+ Exclusion in Salt-Treated Phaseolus vulgaris L. J. Plant Growth Regul. 2009, 28, 187-192. [CrossRef]

55. Fukuda, A.; Tanaka, Y. Effects of ABA, auxin, and gibberellin on the expression of genes for vacuolar $\mathrm{H}^{+}$-inorganic pyrophosphatase, $\mathrm{H}^{+}$-ATPase subunit A, and $\mathrm{Na}^{+} / \mathrm{H}^{+}$antiporter in barley. Plant Physiol. Biochem. 2006, 44, 351-358. [CrossRef] [PubMed]

56. Sawada, H.; Shim, I.-S.; Usui, K. Induction of benzoic acid 2-hydroxylase and salicylic acid biosynthesis modulation by salt stress in rice seedlings. Plant Sci. 2006, 171, 263-270. [CrossRef]

57. Ashraf, M.; Akram, N.A.; Arteca, R.N.; Foolad, M.R. The physiological, biochemical and molecular roles of brassinosteroids and salicylic acid in plant processes and salt tolerance. Crit. Rev. Plant Sci. 2010, 29, 162-190. [CrossRef]

58. El-Tayeb, M.A. Response of barley grains to the interactive e.ect of salinity and salicylic acid. Plant Growth Regul. 2005, 45, 215-224. [CrossRef]

59. El-Mashad, A.A.; Mohamed, H.I. Brassinolide alleviates salt stress and increases antioxidant activity of cowpea plants (Vigna sinensis). Protoplasma 2012, 249, 625-635. [CrossRef]

60. Valencia-Cantero, E.; Hernández-Calderón, E.; Velázquez-Becerra, C.; López-Meza, J.E.; Alfaro-Cuevas, R.; López-Bucio, J. Role of dissimilatory fermentative iron-reducing bacteria in Fe uptake by common bean (Phaseolus vulgaris L.) plants grown in alkaline soil. Plant Soil 2007, 291, 263-273. [CrossRef]

61. Egamberdieva, D.; Wirth, S.; Bellingrath-Kimura, S.D.; Mishra, J.; Arora, N.K. Salt-tolerant plant growth promoting rhizobacteria for enhancing crop productivity of saline soils. Front. Microbial. 2019, 10, 2791. [CrossRef]

62. Abbas, G.; Saqib, M.; Akhtar, J.; Haq, M.A.U. Interactive effects of salinity and iron deficiency on different rice genotypes. J. Plant Nutr. Soil Sci. 2015, 178, 306-311. [CrossRef]

63. Jaiswal, D.K.; Verma, J.P.; Prakash, S.; Meena, V.S.; Meena, R.S. Potassium as an important plant nutrient in sustainable agriculture: A state of the art. In Potassium Solubilizing Microorganisms for Sustainable Agriculture; Meena, V.S., Maurya, B.R., Verma, J.P., Meena, R.S., Eds.; Springer: New Delhi, India, 2016; pp. 21-29.

64. Santi, C.; Bogusz, D.; Franche, C. Biological nitrogen fixation in non-legume plants. Ann. Bot. 2013, 111, 743-767. [CrossRef] [PubMed]

65. Sobti, S.; Belhadj, H.A.; Djaghoubi, A. Isolation and characterisation of the native Rhizobia under hyper-salt edaphic conditions in Ouargla (southeast Algeria). Energy Procedia 2015, 74, 1434-1439. [CrossRef]

66. Goswami, D.; Parmar, S.; Vaghela, H.; Dhandhukia, P.; Thakker, J.N. Describing Paenibacillus mucilaginosus strain N3 as an efficient plant growth promoting rhizobacteria (PGPR). Cogent Food Agric. 2015, 1, 1000714. [CrossRef]

67. Choudhary, D.K. Microbial rescue to plant under habitat-imposed abiotic and biotic stresses. Appl. Microbiol. Biotechnol. 2012, 96, 1137-1155. [CrossRef] [PubMed]

68. Etesami, H.; Beattie, G.A. Mining halophytes for plant growth-promoting halotolerant bacteria to enhance the salinity tolerance of non-halophytic crops. Front. Microbiol. 2018, 9, 148. [CrossRef]

69. Sindhu, S.; Dua, S.; Verma, M.; Khandelwal, A. Growth Promotion of Legumes by Inoculation of Rhizosphere Bacteria; Springer: Berlin/Heidelberg, Germany, 2010; pp. 195-235.

70. Saghafi, D.; Delangiz, N.; Lajayer, B.A.; Ghorbanpour, M. An overview on improvement of crop productivity in saline soils by halotolerant and halophilic PGPRs. 3 Biotech 2019, 9, 261. [CrossRef]

71. Etesami, H.; Mirseyed, H.; Alikhani, H. In planta selection of plant growth promoting endophytic bacteria for rice (Oryza sativa L.). J. Soil Sci. Plant Nutr. 2013, 14, 491-503. [CrossRef]

72. Aznar, A.; Dellagi, A. New insights into the role of siderophores as triggers of plant immunity: What can we learn from animals? J. Exp. Bot. 2015, 66, 3001-3010. [CrossRef]

73. Kavamura, V.N.; Santos, S.N.; Silva, J.L.; Parma, M.M.; Avila, L.A.; Visconti, A.; Zucchi, T.D.; Taketani, R.G.; Andreote, F.D.; Melo, I.S. Screening of Brazilian cacti rhizobacteria for plant growth promotion under drought. Microbiol. Res. 2013, 168, 183-191. [CrossRef]

74. Ramadoss, D.; Lakkineni, V.K.; Bose, P.; Ali, S.; Annapurna, K. Mitigation of salt stress in wheat seedlings by halotolerant bacteria isolated from saline habitats. SpringerPlus 2013, 2, 6. [CrossRef]

75. Saravanakumar, D.; Samiyappan, R. ACC deaminase from Pseudomonas fluorescens mediated saline resistance in groundnut (Arachis hypogea) plants. J. Appl. Microbial. 2007, 102, 1283-1292. [CrossRef]

76. Palaniyandi, S.A.; Damodharan, K.; Yang, S.H.; Suh, J.W. Streptomyces sp. strain PGPA39 alleviates salt stress and promotes growth of 'Micro Tom' tomato plants. J. Appl. Microbiol. 2014, 117, 766-773. [CrossRef]

77. Singh, R.P.; Jha, P.N. Alleviation of salinity-induced damage on wheat plant by an ACC deaminase-producing halophilic bacterium Serratia sp. SL-12 isolated from a salt lake. Symbiosis 2016, 69, 101-111. [CrossRef]

78. Barnawal, D.; Bharti, N.; Maji, D.; Chanotiya, C.S.; Kalra, A. ACC deaminase-containing Arthrobacter protophormiae induces $\mathrm{NaCl}$ stress tolerance through reduced ACC oxidase activity and ethylene production resulting in improved nodulation and mycorrhisation in Pisum sativum. J. Plant Physiol. 2014, 171, 884-894. [CrossRef] 
79. Kiani, M.; Ali, A.; Sultan, T.; Ahmad, R.; Hydar, S. Plant growth promoting rhizobacteria having 1-Aminocyclopropane-1Carboxylic Acid Deaminase to induce salt tolerance in sunflower (Helianthus annus L.). Nat. Resour. 2015, 6, 391-397. [CrossRef]

80. Din, B.U.; Sarfraz, S.; Xia, Y.; Kamran, M.A.; Javed, M.T.; Sultan, T.; Hussain Munis, M.F.; Chaudhary, H.J. Mechanistic elucidation of germination potential and growth of wheat inoculated with exopolysaccharide and ACC-deaminase producing Bacillus strains under induced salinity stress. Ecotoxicol. Environ. Saf. 2019, 183, 109466.

81. Sarkar, A.; Pramanik, K.; Mitra, S.; Soren, T.; Maiti, T.K. Enhancement of growth and salt tolerance of rice seedlings by ACC deaminase-producing Burkholderia sp. MTCC 12259. J. Plant Physiol. 2018, 231, 434-442. [CrossRef]

82. Singh, R.P.; Jha, P.; Jha, P.N. The plant-growth-promoting bacterium Klebsiella sp. SBP-8 confers induced systemic tolerance in wheat (Triticum aestivum) under salt stress. J. Plant Physiol. 2015, 184, 57-67. [CrossRef]

83. Ansari, F.A.; Ahmad, I.; Pichtel, J. Growth stimulation and alleviation of salinity stress to wheat by the biofilm forming Bacillus pumilus strain FAB10. Appl. Soil Ecol. 2019, 143, 45-54. [CrossRef]

84. Bhise, K.K.; Bhagwat, P.K.; Dandge, P.B. Synergistic effect of Chryseobacterium gleum SUK with ACC deaminase activity in alleviation of salt stress and plant growth promotion in Triticum aestivum L. 3 Biotech 2017, 7, 105. [CrossRef]

85. Wang, W.; Wu, Z.; He, Y.; Huang, Y.; Li, X.; Ye, B.C. Plant growth promotion and alleviation of salinity stress in Capsicum annuum L. by Bacillus isolated from saline soil in Xinjiang. Ecotoxicol. Environ. Saf. 2018, 164, 520-529. [CrossRef]

86. Suarez, C.; Cardinale, M.; Ratering, S.; Steffens, D.; Jung, S.; Montoya, A.M.Z.; Geissler-Plaum, R.; Schnell, S. Plant growthpromoting effects of Hartmannibacter diazotrophicus on summer barley (Hordeum vulgare L.) under salt stress. Appl. Soil Ecol. 2015, 95, 23-30. [CrossRef]

87. Panwar, M.; Tewari, R.; Nayyar, H. Native halo-tolerant plant growth promoting rhizobacteria Enterococcus and Pantoea sp. improve seed yield of Mungbean (Vigna radiata L.) under soil salinity by reducing sodium uptake and stress injury. Physiol. Mol. Biol. Plants 2016, 22, 445-459. [CrossRef]

88. Ahmad, M.; Zahir, Z.A.; Asghar, H.N.; Asghar, M. Inducing salt tolerance in mung bean through coinoculation with rhizobia and plant-growth-promoting rhizobacteria containing 1-aminocyclopropane-1-carboxylate deaminase. Can. J. Microbial. 2011, 57, 578-589. [CrossRef]

89. Aeron, A.; Kumar, S.; Pandey, P.; Maheshwari, D.K. Emerging role of plant growth promoting rhizobacteria in agrobiology. In Bacteria in Agrobiology: Crop Ecosystems; Maheshwari, D.K., Ed.; Springer: Berlin/Heidelberg, Germany, 2011; pp. 1-36.

90. Shrivastava, S.; D'Souza, S.; Desai, P. Production of indole-3-acetic acid by immobilised actinomycetes (Kitasatospora sp.) for soil application. Curr. Sci. 2008, 94, 1595-1604.

91. El-Tarabily, K.A.; Sivasithamparam, K. Non-streptomycete actinomycetes as biocontrol agents of soil-borne fungal plant pathogens and as plant growth promoters. Soil Biol. Biochem. 2006, 38, 1505-1520. [CrossRef]

92. Péret, B.; Svistoonoff, S.; Lahouze, B.; Auguy, F.; Santi, C.; Doumas, P.; Laplaze, L. A role for auxin during actinorhizal symbioses formation? Plant Signal. Behav. 2008, 3, 34-35. [CrossRef]

93. Spaepen, S.; Vanderleyden, J. Auxin and plant-microbe interactions. Cold Spring Harb. Perspect. Biol. 2011, 3, a001438. [CrossRef]

94. Djebaili, R.; Pellegrini, M.; Smati, M.; Del Gallo, M.; Kitouni, M. Actinomycete strains isolated from saline soils: Plant growth promoting traits and inoculation effects on Solanum lycopersicum. Sustainability 2020, 12, 4617. [CrossRef]

95. Saghafi, D.; Ghorbanpour, M.; Asgari Lajayer, B. Efficiency of Rhizobium strains as plant growth promoting rhizobacteria on morpho-physiological properties of Brassica napus L. under salinity stress. J. Soil Sci. Plant Nutr. 2018, 18, 253-268. [CrossRef]

96. Abeer, H.; Abdallah, E.F.; Alqarawi, A.A.; Al-Huqail, A.S.; Alshalawi, S.R.; Wirth, S.; Dilfuza, E. Impact of plant growth promoting Bacillus subtilis on growth and physiological parameters of Bassia indica (Indian bassia) grown udder salt stress. Pak. J. Bot. 2015, $47,1735-1741$.

97. Numan, M.; Bashir, S.; Khan, Y.; Mumtaz, R.; Shinwari, Z.K.; Khan, A.L.; Khan, A.; Al-Harrasi, A. Plant growth promoting bacteria as an alternative strategy for salt tolerance in plants: A review. Microbiol. Res. 2018, 209, 21-32. [CrossRef]

98. Ashraf, M.; Hasnain, S.; Berge, O.; Mahmood, T. Inoculating wheat seedlings with exopolysaccharide-producing bacteria restricts sodium uptake and stimulates plant growth under salt stress. Biol. Fertil. Soils 2004, 40, 157-162. [CrossRef]

99. Upadhyay, S.K.; Singh, J.S.; Singh, D.P. Exopolysaccharide-producing plant growth-promoting rhizobacteria under salinity condition. Pedosphere 2011, 21, 214-222. [CrossRef]

100. Zhang, Z.J.; Chen, S.H.; Wang, S.M.; Luo, H.Y. Characterisation of extracellular polymeric substances from biofilm in the process of starting-up a partial nitrification process under salt stress. Appl. Microbiol. Biotechnol. 2011, 89, 1563-1571. [CrossRef]

101. Qurashi, A.W.; Sabri, A.N. Bacterial exopolysaccharide and biofilm formation stimulate chickpea growth and soil aggregation under salt stress. Braz. J. Microbiol. 2012, 43, 1183-1191. [CrossRef] [PubMed]

102. Mantelin, S.; Touraine, B. Plant growth-promoting bacteria and nitrate availability: Impacts on root development and nitrate uptake. J. Exp. Bot. 2004, 55, 27-34. [CrossRef] [PubMed]

103. Ryu, C.-M.; Farag, M.A.; Hu, C.-H.; Reddy, M.S.; Wei, H.-X.; Paré, P.W.; Kloepper, J.W. Bacterial volatiles promote growth in Arabidopsis. Proc. Natl. Acad. Sci. USA 2003, 100, 4927. [CrossRef]

104. Zhang, H.; Kim, M.S.; Krishnamachari, V.; Payton, P.; Sun, Y.; Grimson, M.; Farag, M.A.; Ryu, C.M.; Allen, R.; Melo, I.S.; et al. Rhizobacterial volatile emissions regulate auxin homeostasis and cell expansion in Arabidopsis. Planta 2007, 226, 839-851. [CrossRef] 
105. Ledger, T.; Rojas, S.; Timmermann, T.; Pinedo, I.; Poupin, M.J.; Garrido, T.; Richter, P.; Tamayo, J.; Donoso, R. Volatile-mediated effects predominate in Paraburkholderia phytofirmans growth promotion and salt stress tolerance of Arabidopsis thaliana. Front. Microbiol. 2016, 7, 1838. [CrossRef] [PubMed]

106. Barihi, R.; Panahpour, E.; Beni, M.H.M. Super absorbent polymer (hydrogel) and its application in agriculture. World Sci. J. 2013, 1,223-228.

107. Karimi, E.; Rohani, H.; Zafari, D.; Khodakaramian, G.; Taghinasab, M. Biological control of vascular wilt disease of carnation caused by Fusarium oxysporum f. sp. dianthi by Bacillus and Pseudomonas strains isolated from rhizosphere of carnation. J. Sci. Technol. Agric. Nat. Resour. 2007, 11, 309-320.

108. Verma, A.; Thakur, S.; Mamba, G.; Gupta, R.K.; Thakur, P.; Thakur, V.K. Graphite Modified Sodium Alginate Hydrogel Composite for Efficient Removal of Malachite Green Dye. Int. J. Biol. Macromol. 2020, 148, 1130-1139. [CrossRef]

109. Moradi-Pour, M.; Saberi-Riseh, R.; Mohammadinejad, R.; Hosseini, A. Nano-encapsulation of plant growth-promoting rhizobacteria and their metabolites using alginate-silica nanoparticles and carbon nanotube improves ucb1 pistachio micropropagation. J. Microbiol. Biotechnol. 2019, 29, 1096-1103. [CrossRef] [PubMed]

110. Blumwald, E. Sodium transport and salt tolerance in plants. Curr. Opin. Cell Biol. 2000, 12, 431-434. [CrossRef]

111. Mayak, S.; Tirosh, T.; Glick, B.R. Plant growth-promoting bacteria confer resistance in tomato plants to salt stress. Plant Physiol. Biochem. 2004, 42, 565-572. [CrossRef] [PubMed]

112. Sun, X.F.; Li, C.; Wu, Z.S.; Xu, X.L.; Ren, L.; Zhao, H.S. Adsorption of protein from model wine solution by different bentonites China J. Chem. Eng. 2007, 15, 632-638. [CrossRef]

113. Wu, Z.S.; He, Y.H.; Chen, L.J.; Han, Y.J.; Li, C. Characterisation of R. planticola Rs-2 microcapsule prepared with a blend of alginate and starch and its release behavior. Carbohyd. Polym. 2014, 110, 259-267. [CrossRef]

114. Wu, Z.S.; Zhao, Y.F.; Kaleem, I.; Li, C. Preparation of calcium alginate microcapsuled microbial fertiliser coating Klebsiella oxytoca Rs-5 and its performance under salinity stress. Eur. J. Soil Biol. 2011, 47, 152-159. [CrossRef]

115. Afzal, M.; Shabir, G.; Tahseen, R.; Islam, E.; Iqbal, S.; Khan, Q.M.; Khalid, Z.M. Endophytic Burkholderia sp. strain PsJN improves plant growth and phytoremediation of soil irrigated with textile effluent. CLEAN-Soil Air Water 2014, 42, 1304-1310. [CrossRef]

116. Afzal, M.; Khan, S.; Iqbal, S.; Mirza, M.S.; Khan, Q.M. Inoculation method affects colonisation and activity of Burkholderia phytofirmans PsJN during phytoremediation of diesel-contaminated soil. Int. Biodeter. Biodegr. 2013, 85, 331-336. [CrossRef]

117. Anandham, R.; Choi, K.H.; Gandhi, P.I.; Yim, W.J.; Park, S.J.; Kim, K.A.; Madhaiyan, M.; Sa, T.M. Evaluation of shelf life and rock phosphate solubilisation of Burkholderia sp. in nutrient-amended clay, rice bran and rock phosphate-based granular formulation. World J. Microb. Biot. 2007, 23, 1121-1129. [CrossRef]

118. Minaxi, J.; Saxena, J. Efficacy of rhizobacterial strains encapsulated in nontoxic biodegradable gel matrices to promote growth and yield of wheat plants. Appl. Soil Ecol. 2011, 48, 301-308. [CrossRef]

119. Semary, N.A.H.; Alouane, M.H.; Nasr, O.; Aldayel, M.F.; Alhaweti, F.H.; Ahmed, F. Salinity stress mitigation using encapsulated biofertilizers for sustainable agriculture. Sustainability 2020, 12, 9218. [CrossRef]

120. Çavusoglu, K.; Kabar, K. Effects of hydrogen peroxide on the germination and early seedling growth of barley under $\mathrm{NaCl}$ and high temperature stresses. Eurasian J. Biosci. 2010, 4, 70-79. [CrossRef]

121. Padorf, M.; Pourzahedi, L.; Gilbertson, L.; Lowry, G.V.; Herckes, P.; Westerhoff, P. Graphite nanoparticle addition to fertilisers reduces nitrate leaching in growth of lettuce (Lactuca sativa). Environ. Sci. 2020, 7, 127-138.

122. Semary, N.A.; Fouda, M. Anticancer activity of Cyanothece sp. strain extracts from Egypt: First record. Asian Pac. J. Trop. Biomed. 2015, 5, 992-995. [CrossRef]

123. Trejo, A.; de-Bashan, L.E.; Hartmann, A.; Hernandez, J.P.; Rothballer, M.; Schmid, M.; Bashan, Y. Recycling waste debris of immobilised microalgae and plant growth-promoting bacteria from wastewater treatment as a resource to improve fertility of eroded desert soil. Environ. Exp. Bot. 2012, 75, 65-73. [CrossRef]

124. Wu, B.Z.; Peng, Y.; Guo, L. Chun Li Root colonisation of encapsulated Klebsiella oxytoca Rs-5 on cotton plants and its promoting growth performance under salinity stress. Eur. J. Soil Biol. 2014, 60, 8187. [CrossRef]

125. Komal, K.B.; Padma, B.D. Alleviation of salinity stress in rice plant by encapsulated salt tolerant plant growth promoting bacteria Pantoea agglomerans strain KL and its root colonisation ability. Arch. Acker. 2019, 65, 1955-1968.

126. Augustine, T.Z.; Lima, E.; Suna, H.; Marelli, B. A bioinspired approach to engineer seed microenvironment to boost germination and mitigate soil salinity. Sci. J. Biol. Sci. 2019, 116, 25555-25561.

127. Abo-Kora, H.A.; Maie, M.A. Reducing effect of soil salinity through using some strains of Nitrogen fixers bacteria and compost on sweet basil plant. Int. J. Pharmtech. Res. 2016, 19, 187-214.

128. Ordookhani, K.; Khavazi, K.; Moezzi, A.; Rejali, F. Influence of PGPR and AMF on antioxidant activity, lycopene and potassium contents in tomato. Afr. J. Agric. Res. 2010, 5, 1108-1116.

129. Fathy, N.O. Impact of compost on the availability and nutrients content of Vicia faba grown on saline waterirrigated soil. Minufiya J. Agr. Res. 2010, 35, 1573-1585.

130. Baniaghil, N.; Arzanesh, M.H.; Ghorbanli, M.; Shahbazi, M. The effect of plant growth promoting rhizobacteria on growth parameters, antioxidant enzymes and microelements of Canola under salt stress. J. Appl. Environ. Biol. Sci. $2013,3,17-27$.

131. Maged, M.; Abo-Koura, H.A.; Bishara, M.M.; Gomaa, I.M. Microencapsulation: Toward the Reduction of the Salinity Stress Effect on Wheat Plants Using NPK Rhizobacteria. Biotechnol. J. Int. 2019, 23, 1-18. 
132. Kang, S.M.; Khan, A.L.; Waqas, M.; You, Y.H.; Kim, J.H.; Kim, J.G.; Hamayun, M.; Lee, I.J. Plant growth-promoting rhizobacteria reduce adverse effects of salinity and osmotic stress by regulating phytohormones and antioxidants in Cucumis sativus. J. Plant Interact. 2014, 9, 673-682. [CrossRef]

133. Nozhkina, O.A.; Perfileva, A.I.; Graskova, I.A.; Dyakova, A.V.; Nurminsky, V.N.; Klimenkov, I.V.; Ganenko, T.V.; Borodina, T.N.; Aleksandrova, G.P.; Sukhov, B.G.; et al. The Biological Activity of a Selenium Nanocomposite Encapsulated in Carrageenan Macromolecules with Respect to Ring Rot Pathogenesis of Potato Plants. Nanotechnol. Russ. 2019, 14, 255-262. [CrossRef] 